\title{
Entorno y Educación: Un Tejido Invisible. Un Viaje de la Ciudad al Aula
}

\author{
Environment and Education: An Invisible Tissue. A Journey \\ from the City to the Classroom
}

\section{Ambiente e Educação: Um Tecido Invisível. Uma Viagem da Cidade para a Sala de Aula}

\author{
Clara Eslava * \\ Universidad Antonio de Nebrija
}

\begin{abstract}
Nos preguntamos por la naturaleza del vínculo entre entorno y educación, por la definición del entorno como un hecho en sí mismo educativo. Mediante la definición de un contexto teórico, desvelamos su concepción como fuente de experiencias, como red de relaciones o como constructo transformador de la propia realidad en que se inserta. Lo haremos en base a una metáfora, la de "un tejido invisible" que emerge cosiendo el entorno con la acción educativa. Por último, cuestionaremos las fórmulas actualmente generalizadas que relacionan rígidamente arquitecturas y pedagogías, buscando un diálogo abierto entre entorno y educación.
\end{abstract}

Descriptores: Medio ambiente, Educación, Óptica, Ciudad, Escuela.

\begin{abstract}
We ask ourselves about the nature of the link between environment and education, for the definition of the environment as an educational fact in itself. Through the definition of a theoretical context, we reveal its conception as a source of experiences, as a network of relationships or as a transformative construct of the reality in which it is inserted. We will do it based on a metaphor, that of "an invisible tissue" that emerges by sewing the environment with educational action. Finally, we will question the currently generalized formulas that rigidly relate architectures and pedagogies, seeking an open dialogue between environment and education.
\end{abstract}

Keywords: Environment, Education, Optics, City, School.

Questionamos a natureza do vínculo entre o meio ambiente e a educação pela definição do meio ambiente enquanto ferramenta educacional. Ao criar um enquadramento teórico, definimos a sua conceção como fonte de experiência, como rede de relações e como elemento transformador da própria realidade na qual se insere. A metáfora do "tecido invisível” à volta do qual é tecida a ação educativa servirá como ponto de partida. Finalmente será questionada a formula, atualmente generalizada, que considera a relação rígida entre arquitetura e pedagogia, à procura de um dialogo aberto entre envolvente e educação.

Palavras-chave: Meio ambiente, Educação, Ótica, Cidade, Escola.

*Contacto: cec@eaaestudio.com

ISSN: 2254-3139

www.rinace.net/riejs/

revistas.uam.es/riejs
Recibido: $\quad 1$ de diciembre 2016

$1^{\text {a }}$ Evaluación: 13 de enero 2017

$2^{\text {a }}$ Evaluación: 28 de febrero 2017

Aceptado: $\quad 14$ de marzo 2017 


\section{Tejiendo entornos educativos}

La importancia pedagógica del entorno surge a partir de un enfoque que considera la capacidad y autonomía del niño en la propia construcción del conocimiento, lo que permite el desarrollo de sus iniciativas en libertad. Recíprocamente, y dado que se otorga al ambiente un papel educador, se requiere un trabajo sobre el ambiente como membrana de mediación entre el niño y el mundo.

Antes de aceptar este planteamiento, intentaremos, sin embargo, volver a su inicio, cuestionándolo; así, pondremos encima de la mesa una pregunta clave en el contexto que nos ocupa, de reflexión conjunta de arquitectos y educadores: ¿Podemos considerar el entorno un hecho educativo en sí mismo? Pero ¿qué es entorno? ¿Qué es educación? Los entornos educativos, ¿importan? (figura 1).

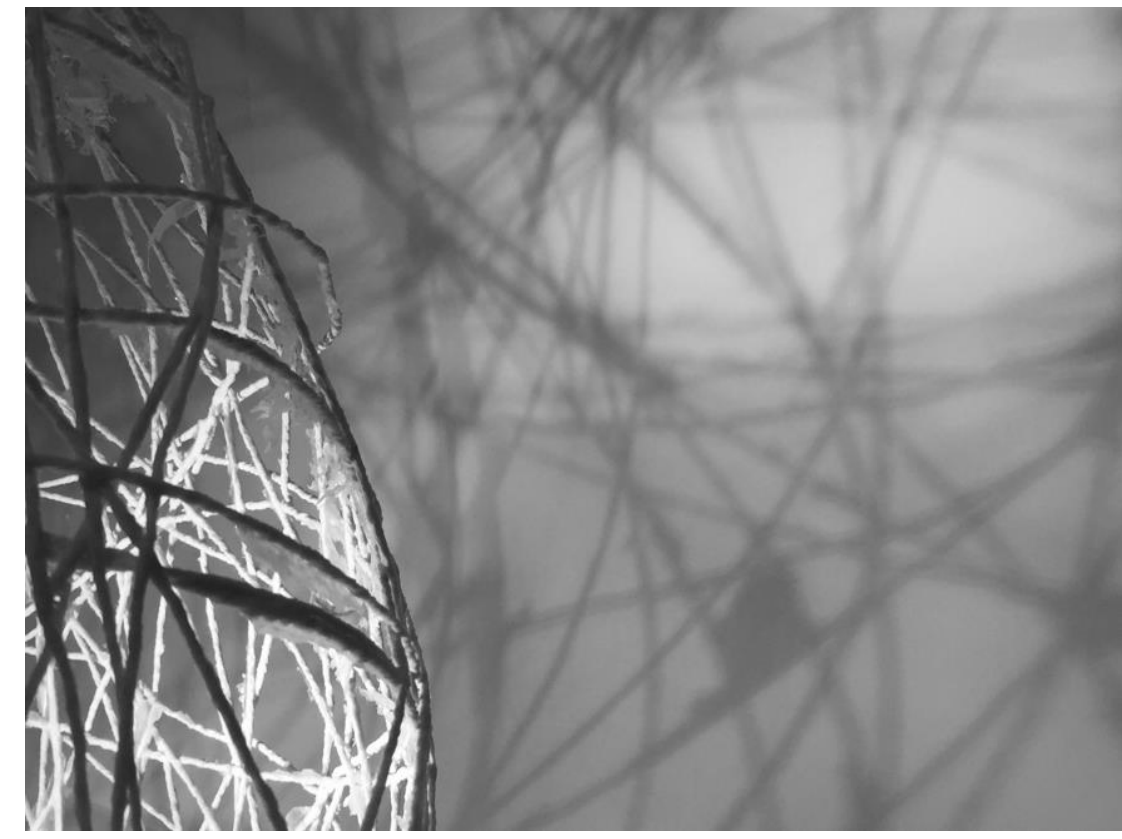

Figura 1. Fragmento de un espacio imaginario, maqueta

Fuente: Elaborado por Lallana (2016).

\subsection{Imaginando escenarios}

Imaginemos por un momento un entorno inadmisible por una razón cualquiera y consideremos en él una acción educativa; esta será posiblemente y con toda seguridad más constructiva que nunca: ¿podemos concluir entonces que el entorno no importa?

Imaginemos ahora un entorno tan neutro como sea posible, gris, sin intencionalidad ninguna, absolutamente carente de significación, y consideremos en él un extraordinario equipo docente; la acción educativa será posible y con toda seguridad excelente: ¿podemos concluir entonces que el entorno no importa?

Imaginemos por último un entorno educativo óptimo, pleno en sus potencialidades, coherente y adecuado a un proyecto pedagógico innovador; pero éste último no se lleva a cabo, traicionando al entorno con una pedagogía obsoleta y perpetuando modelos pretéritos: ¿podemos concluir entonces que el entorno no importa? 
La respuesta a esta pregunta implica una toma de posición, pero no se trata de adoptar un mero "a favor" o "en contra"; no se trata de resolver un dilema dialéctico, sino de construir un punto de vista, un enfoque que nos permita reflexionar sobre esta cuestión de forma necesariamente compleja.

\subsection{La metáfora del tejido}

Intentaremos a continuación esbozar posibles respuestas; lo haremos en primer lugar imaginando y sintiendo el entorno que habitamos a partir de las imágenes que nos ofrece la anciana metáfora del tapiz: una metamorfosis continua que transforma de la lana informe en el hilo, del hilo en tejido, y del tejido en tapiz, representando con sus figuras una visión del mundo.

$\mathrm{Si}$ 'entorno' fuera la experiencia incomunicada de nuestras vivencias internas individuales o colectivas... Estas experiencias constituirían quizás la materia de los hilos y sus colores, creados por la mano de la hilandera, el huso o la rueca que hilan la materia informe de la lana.

Si 'entorno' fuera la relación intangible que se teje entre los sujetos, como hilos que nos conectan, comunicantes de las experiencias vividas... Estas relaciones constituirían quizás los hilos del telar que se cruzan, que se anudan y se tejen...

$\mathrm{Si}$ 'entorno' fuera la transformación invisible de estas experiencias y relaciones en un todo, la construcción que integra a su vez la materia de aquellas experiencias vividas y los vínculos de las relaciones... Esta construcción última sería entonces el propio tejido, su trama y urdimbre serian estructuras vivas; el tejido sería la tela con que envolvemos nuestros cuerpos o con la que construimos la primera cueva y que -como un tapiz- se carga de significado, generando una narrativa del mundo. En nuestra metáfora, entorno es el tapiz que tejen nuestras vidas, las de toda la comunidad educativa. Las imágenes que porta, constituyen una visión del mundo.

Un entorno educativo reproduce un doble papel, su propia constitución y la mirada reflexiva sobre sí mismo como escenario. Un escenario que asume el papel de hacer visibles dichas experiencias, relaciones y transformaciones, de evidenciarlas y permitir la toma de conciencia sobre ellas. Un entorno, si es educativo, debe reflexionar sobre sí mismo, debe "conocer el conocer" y mostrarlo, reflejarlo en su acontecer, hacerlo aflorar hasta manifestarlo como una revelación. Volviendo a nuestra metáfora, "el tejido invisible" se suelta del telar y se instala en el mundo, se hace visible: es a la vez traje y hábitat que cose los momentos educativos.

\subsection{El hecho cognitivo}

Pero veamos si es posible otro acercamiento: ¿cómo analizar, si no es a través de la metáfora poética, "un mundo de entornos"? Si aceptamos que "el camino se hace al andar", seremos capaces de aproximarnos como observadores a una realidad compleja y cambiante, de la cual somos partícipes. Pero este modo operativo transforma las afirmaciones en dudas y las certezas en incertidumbre; se trata de poder avanzar hacia lo desconocido en base a hipótesis, construyendo preguntas sobre la realidad. ¿Si el diálogo enseñanza y aprendizaje se produce en la vida, cualquier entorno vivido puede ser educativo? $\mathrm{O}$, por el contrario, ¿debemos considerar entorno educativo únicamente a aquel que propicie un escenario óptimo de enseñanza y aprendizaje? O bien... ¿Existe 
realmente un entorno educativo, o éste es un constructo que nos acompaña y se transforma en la experiencia de enseñanza \& aprendizaje?

Aproximarnos a la educación implica una reflexión sobre el hecho cognitivo, la apertura de una ventana que mira cómo miramos a través de otra: El conocimiento del conocimiento (Morin, 1986). Siguiendo a Edgar Morin, el conocimiento es inseparable de la acción: "el conocimiento es a la vez actividad y producto de esta actividad" (p. 220). El contacto entre vida y conocimiento es un bucle circular, pues "el conocimiento de la vida nos introduce en la vida del conocimiento de una forma extraordinariamente íntima” (Morin, 1986, p. 222). Esta intrínseca unión entre conocimiento y vida se traduce en el diálogo indisoluble entre múltiples binomios que históricamente se han escindido como opuestos: la complementariedad entre lo cognitivo y lo sensible, lo mental y lo corporal, la razón y la emoción, o la fusión entre la lógica y la intuición, el aprendizaje y el juego o la memoria y la imaginación...

En coherencia con los planteamientos de Morin (1986), podríamos trazar una hipótesis y considerar entorno educativo todo aquel que se configure como una zona de adecuación cognitiva:

Si existe una correspondencia entre los principios organizacionales de nuestro
conocimiento y los principios organizacionales del mundo fenoménico, esto nos
indica que podemos elaborar traducciones cognitivas adecuadas que estén en
correspondencia cognitiva con los fenómenos. [ ‥] La correspondencia cognitiva
que se establece de este modo puede ser considerada como una suerte de puesta en
resonancia entre el cognoscente, su conocimiento y lo cognoscible. (pp. 238-239)

Un entorno educativo, debería por tanto entrar en resonancia y ofrecer una consciencia de sí mismo como entorno en relación al cognoscente. Se trata, siguiendo el enfoque de Humberto Maturana y en palabras de Francisco Varela, de un escenario que permita el "acoplamiento estructural"1 entre el sujeto y el mundo de forma óptima.

No podemos separar, sin embargo, conocimiento y emoción, que concebimos en complementariedad dialógica. Añadiremos hoy un paso más y consideraremos entorno educativo todo aquel que se configure como una zona de adecuación cognitiva y emocional. La integración de las emociones cuenta con un largo recorrido en el campo pedagógico. Desde el campo de la arquitectura y del diseño, el término "emocional" se emplea desde una doble aproximación: en arquitectura la emoción tendría como núcleo la conmoción provocada en la experiencia estética; en diseño la emoción se construye y estudia desde una aproximación global a la experiencia de usuario; en arquitectura podemos hablar de un rescate creativo de la riqueza sensorial y simbólica que enunciara ya la fenomenología del espacio y especialmente las poéticas del espacio de Gaston Bachelard; sin embargo, en diseño podemos hablar de un enriquecimiento de la noción racionalista de función donde la finalidad utilitaria resulta inseparable del vínculo emocional, según defiende Donald Norman en su obra "El diseño emocional" (2005).

Fritjof Capra (1996) sintetiza en "La trama de la vida" los principios del "pensamiento sistémico" (p. 49) para hablar de los sistemas vivos; en consecuencia, resulta especialmente adecuado para acercarnos a la comprensión de los entornos, en nuestro caso educativos. Se trata de un método contextual que parte del predominio de todo y las

${ }^{1}$ Francisco Varela explica de forma intuitiva el concepto de "acoplamiento estructural”, con la imagen de la forma que construyen mutua y simultáneamente dos bloques de hielo que se funden en un vaso que los contiene. 
relaciones entre las supuestas partes (pues concluye que no existen como tales), para estudiar las relaciones, los principios esenciales de organización: "la trama de la vida está constituida por redes dentro de redes" (p. 54).

A su vez, siguiendo los planteamientos de Capra (1996), el enfoque sistémico se relaciona con la "ecología profunda"; esta última cose en un mismo tejido el mundo natural y el cultural, pues "reconoce el valor intrínseco de todos los seres vivos y ve a los humanos como una mera hebra de la trama de la vida" (p. 29). El vínculo entre naturaleza y cultura, nuestra comprensión de la naturaleza en el seno mismo de la cultura, es necesaria para sumergirnos en aquellos estadios primigenios de la infancia donde "lo biológico y lo cultural" 2 se funden, se entrelazan íntimamente en procesos de mutua conformación. Desde esta simbiosis, nos acercamos a la noción de "experiencia" como un constructo del in-between $n^{3}$ entre el niño y el mundo (Hertzberger, 1991). Con las propuestas de entornos educativos, constituimos posibles interfaces para ese in-between, herramientas de mediación, membranas o burbujas que conforman un espacio vital y de aprendizaje (figura 2 ).

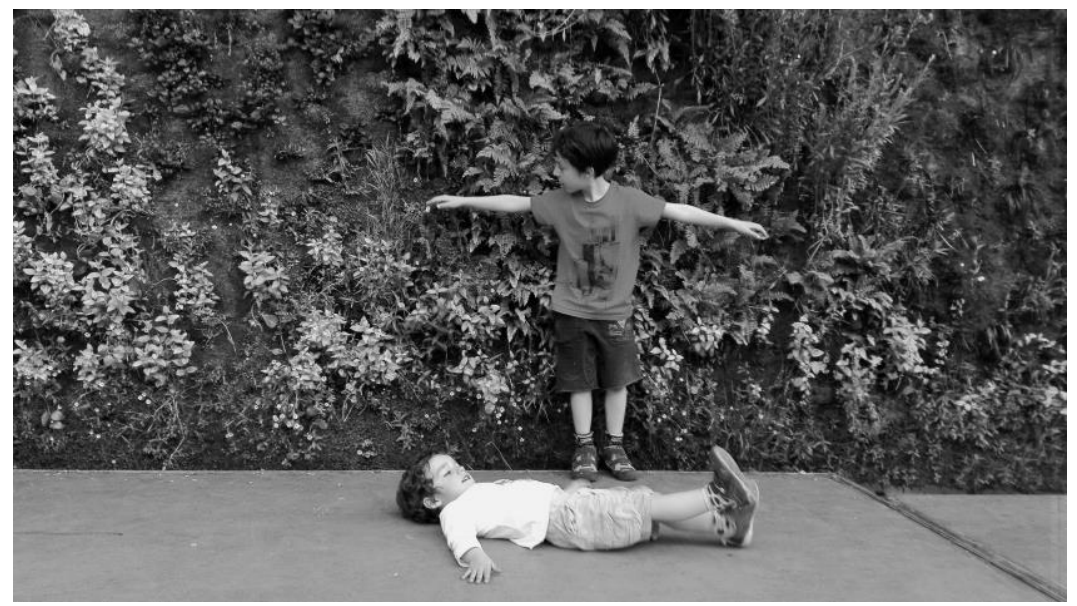

Figura 2. Los niños experimentan espacio y materia con sus cuerpos, en diálogo con el entorno

Fuente: Elaborado por Eslava (2016).

\subsection{La educación como experiencia vital}

Vida y conocimiento se unen: educar es "enseñar a aprender a vivir". En su "Manifiesto para cambiar la educación”, Edgar Morin (2015) define el sentido de la educación como "ayudar a aprender a vivir", titulando el libro: "Enseñar a vivir". El filósofo nos interroga: “Qué significa vivir? Para el autor, la palabra vivir tiene un primer sentido: estar vivo. Pero alcanza un sentido pleno cuando se diferencia vivir de sobrevivir. Sobrevivir es subvivir" (Morin, 2015, p. 23). En nuestro acercamiento al binomio

\footnotetext{
${ }^{2}$ La cuestión de las relaciones entre naturaleza y cultura no consiste hoy en día en el acuerdo o el desacuerdo entre dos mundos territorialmente distintos: "Sería más bien la de la delimitación y la articulación, en el seno mismo de la cultura, de lo que puede ser designado, pensado, vivido, como 'la naturaleza', Disponible en: http://www.hypergeo.eu/IMG/_article_PDF/article_280.pdf.

${ }^{3} \mathrm{El}$ arquitecto Herman Hertzberger -heredero de los planteamientos que Aldo van Eyck expresara en su texto "The Inbetween Realm" (1962)-, reubica el concepto de "in-between" conectándolo, en sus reflexiones sobre la enseñanza de la arquitectura tanto como en sus proyectos de escuelas, con el mundo de la infancia.
} 
“entorno y educación” deberíamos revindicar también dicha plenitud. Se trata también de "vivir" los entornos educativos, no sólo de "sobrevivir" a ellos.

La mayor parte de las sociedades viven alternando el vivir, y el sobrevivir dicho, en otros términos, se convive entre lo prosaico y lo poético. Comprender los entornos educativos desde esta misma alternancia nos permitiría hacer convivir en ellos lo prosaico, como la alfabetización, con lo poético y el juego creativo. Siguiendo a Morin (2015), "llegamos a la idea de que la aspiración al bien vivir requiere de la enseñanza de un saber-vivir en nuestra civilización. Vivir se sitúa concretamente en un tiempo y en un lugar" (p. 23).

La construcción de entornos, es una forma de mediación propia de cada civilización, con sus tiempos y sus lugares. Los entornos educativos deberían formar parte de esta tarea doblemente. En su dimensión vital -permitiendo construir a los niños y niñas sus experiencias de vida- y en su dimensión pedagógica -permitiéndoles construir sus narrativas del mundo-. Si educar fuera, como señala Morin (2015), enseñar a aprender a vivir, entonces entornos educativos serían aquellos que, desde el contexto, enseñan a aprender a vivir.

Se trata de una tarea que, como adultos, debemos asumir desde el compromiso ético de buscar lo óptimo: hacer posibles los mejores entornos educativos. Pero esta afirmación encierra de nuevo un interrogante esencial: ¿qué es lo óptimo?

Es necesario un acercamiento al concepto de lo óptimo teniendo en cuenta la flexibilidad ecológica que decía el antiguo refrán: "lo mejor enemigo de lo bueno"; o expresado en términos científicos: "no hay supervivencia del más adaptado, hay supervivencia del adaptado” (Maturana y Várela, 1984 p. 75). El teórico del diseño Ezio Manzini realiza una síntesis de la "evolución de las teorías evolutivas", en un acercamiento desde las teorías de la complejidad, planteando como clave concepto de suboptimalidad: lo óptimo es lo subóptimo; requiere flexibilidad frente a rigidez; polivalencia frente a especialización; admisibilidad del error frente a colapso: en conclusión, frente a la imposición de la respuesta única, la auto-organización y metamorfosis continua de la diversidad (figura 3).
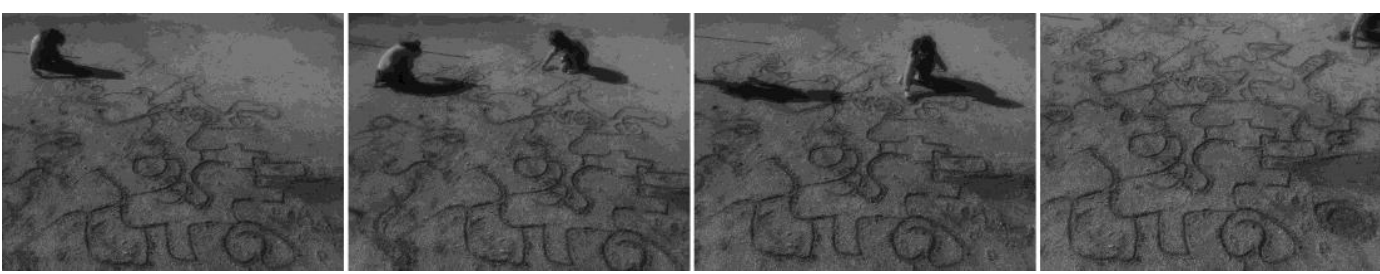

Figura 3. La riqueza del juego plástico de dos niñas que trazan un mundo complejo Fuente: Elaborado por García-Setién (2013).

¿Cómo trasladar este enfoque del campo de la ciencia al diseño del hábitat y a los entornos educativos? Parece claro que, como mínimo, no podemos plantear hoy como respuesta la correspondencia biunívoca entre modelos arquitectónicos y pedagógicos. El diálogo entre disciplinas convergía -en determinados momentos históricos- en extraordinarias correspondencias entre modelos que se han estudiado como hilo conductor de las historias de la arquitectura escolar. Pero en nuestra cultura contemporánea no buscamos necesariamente la cristalización de correspondencias, sino 
la posibilidad de generar de forma flexible un amplio rango de diversas respuestas viables: pluralidad de entornos son posibles.

¿Qué sucede con los espacios actualmente considerados educativos? Podemos afirmar que predomina de forma alarmante un único modelo, el que se inserta en una educación dentro del marco de la escuela graduada por edades y donde los papeles de niños y adultos se encuentran nítidamente delimitados. Se trata de una escuela que hereda los mecanismos y lógicas lineales tanto del evolucionismo como del productivismo del desarrollo industrial decimonónico. Las arquitecturas escolares dan buena cuenta de ello: división por niveles y por plantas, con largos pasillos y aulas separadas por puertas bien cerradas. Conscientes de la larga inercia que lastra el sistema, debemos hoy buscar otros entornos educativos, los de nuestro tiempo.

Así, podemos incluso señalar que la finalidad de los espacios que generalmente identificamos como destinados al aprendizaje sólo resulta educativa si los contemplamos dentro del sistema actualmente predominante, que podemos definir críticamente en los términos en que Pineau, Dussel y Caruso (2001) habla de "la escuela: como máquina de educar", una construcción social cuyo triunfo se integra como producto de la modernidad; en este sentido, el autor nos muestra la modernidad como la “identificación”, la correspondencia biunívoca entre la escuela y la educación, acuñando una determinada noción de infancia.

Se trata de un enfoque portador de una doble herencia que se refleja con exactitud en los modelos pedagógicos y arquitectónicos que lo representan: por un lado, la escisión entre conocimiento y vida; por otro lado, el carácter productivista, no altruista, de su propósito; es decir, se trata de una escuela que propugna por encima de la vida la supervivencia del sistema, una escuela del subvivir, en los términos de Morin, una escuela predominantemente prosaica y escasamente poética, cuando su plenitud radicaría en integrar ambos registros.

Parece posible hablar hoy de una "modernidad superada" (Montaner, 1997), y romper por tanto la hegemonía de la escuela como contexto único educativo. Así, podemos rescatar hoy otros entornos para la educación: desde la ciudad hasta el hogar, desde los juegos estructurados a los espontáneos; los entornos educativos del mundo posterior a lo moderno, en su crisis, se han expandido.

Paralelamente, Norberto Chaves (2005) redefine "el diseño invisible" como la función de la arquitectura o la intervención culta que hace de la naturaleza el hábitat humano; en su discurso, nos habla sobre una profunda revisión de los dogmáticos principios de la modernidad: "El hábitat sintetiza en cada uno de sus rasgos la totalidad de niveles de la experiencia humana: lo biológico, lo psicológico, lo ergonómico, lo tecnológico, lo económico, lo político etc.” (p. 20). Chaves expresa como las teorías del hábitat o de la arquitectura que emprenden un enfoque parcial (funcionalismos, tecnologicismos, economicismos, esteticismos...) son planteamientos parciales e insuficientes, resultan reduccionistas y bloquean la comprensión del hábitat, cuando pretenden regular su producción: "las ideologías del diseño y de la arquitectura han incurrido insistentemente en este tipo de simplificación” (Chaves, p. 20).

Se trata de un pensamiento que acepta la complejidad, desde autores que convergen en una misma crítica de la modernidad, haciendo evidente la necesidad de la reformulación 
de los actuales modelos de escuela tanto en cuanto a su arquitectura como a su pedagogía.

En respuesta crítica al racionalismo de la modernidad se formula un "cambio de paradigma", una transformación de "una constelación de conceptos, valores, percepciones y prácticas compartidos por una comunidad, que conforman una visión particular de la realidad que, a su vez, es la base del modo en que dicha comunidad se organiza" (Capra, 1996, p. 27) . Es quizás el "emerger" de este cambio como surgimiento y la 'emergencia' como urgencia del mismo en la postmodernidad, el escenario que propicia la reflexión sobre los términos "entorno y educación" de forma holista, compleja, ecológica (figura 4).

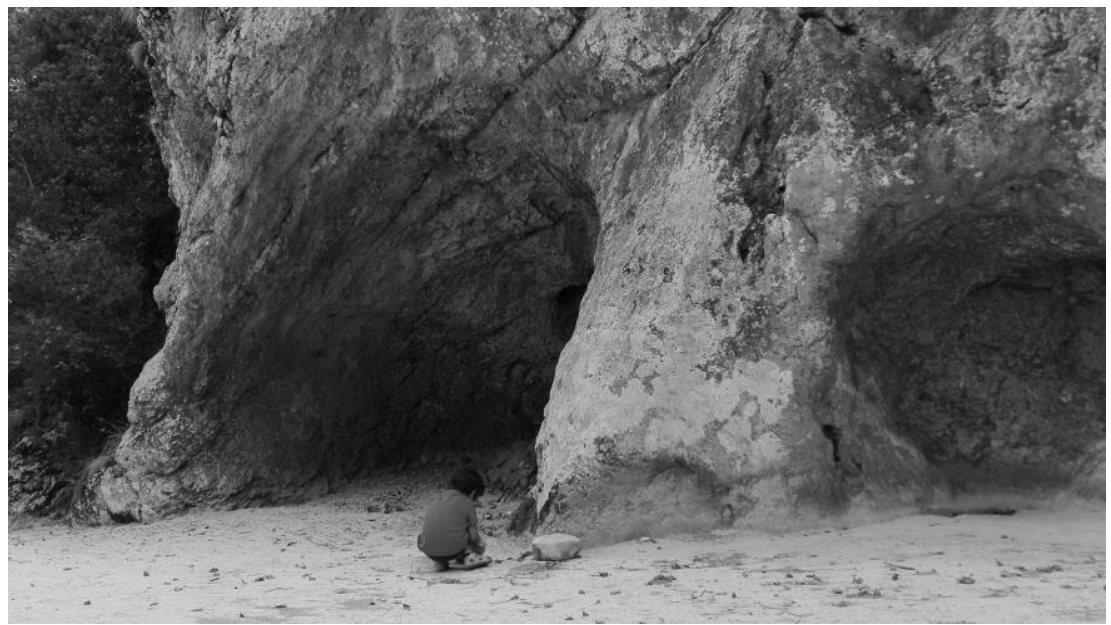

Figura 4. Los espacios de la naturaleza en diálogo con el niño que explora su complejidad

Fuente: Elaborado por Eslava (2016).

No obtendremos, en definitiva, respuestas definitivas, sino redes de conceptos, no obtendremos objetos resultantes, sino relaciones posibles; no permaneceremos como observadores, sino que nuestra pregunta, formulada a la realidad, la transformará inevitablemente, cambiando nuestra visión sobre ella.

No pretendemos predeterminar los resultados, ni determinar qué arquitecturas para que educación, sino generar un tejido de conocimientos y una forma de mirar desde los cuales acompañar procesos; éstos -desde planteamientos complejos- pueden conducir a acciones efectivas muy sencillas. Aunar complejidad y sencillez requiere un cambio de paradigma, un cambio de mirada que no se producirá espontáneamente, sino que debemos construir participativamente.

\footnotetext{
${ }^{4}$ Un "nuevo paradigma” tomando el término que acuña Thomas Kuhn.

${ }^{5}$ Fritjof Capra propone superar el paradigma de la modernidad, desarrollando una visión integral de la vida donde todo se encuentra en mutua dependencia, un enfoque que integra la tradición sistémica, la holística y la ecología profunda. Un "nuevo paradigma" que cambia nuestros pensamientos y valores superando la visión mecanicista y patriarcal, ubicando además lo femenino como una variable fundamental del cambio.
} 


\subsection{Un recorrido, una forma de mirar}

Nos interrogaremos a continuación sobre las formas de observar, participar y relatar los entornos que habitamos; buscando transformar nuestra mirada, nos acompañamos con una segunda metáfora, la de la visión con "lente ojo de pez", con cuya óptica trazaremos un recorrido por escenarios diversos, desde la escala de la ciudad al ámbito del aula. La concepción de cada uno de estos escenarios como fragmentos insertados en redes nos ayudará a intuir la complejidad de un mundo que no podemos disociar en su análisis.

Al escudriñar el mundo, nuestra mirada investigadora parece emplazarse necesariamente en un plano de observación sobre el fenómeno que estudia; sin embargo, desde los planteamientos de las teorías de Maturana y Varela, el observador dista mucho de ser un abstracto ojo neutro y el plano de observación no es en absoluto una plataforma o atalaya ajena a la realidad. Se trata, por el contrario, de una realidad participada, que implica la transformación de lo observado en el propio proceso investigador: cuando investigamos, trazamos una narrativa de la vida que forma parte de la vida misma: "sólo hay redes dentro de redes" (Capra, 1996, p. 54). No somos, en consecuencia, observadores externos a lo observado, sino que nos integramos en redes; así, la burbuja flotando en el aire se funde a otras, deformadas, poliédricas, conformando la imagen de la espuma que recorre en su obra Peter Sloterdijk (1998).

Miramos alrededor nuestra y el entorno que habitamos parece ajeno a nuestras reflexiones y preguntas. Soñamos nuevos escenarios educativos pero la realidad se resiste al cambio. Buscamos otra forma de mirar la realidad pues queremos que, cada día, todo aquello que nos rodea nos devuelva la mirada. Ello nos obliga a una mirada ética, en la que la propia acción investigadora se comprometa y devenga, inversamente, investigación-acción (Elliott, 1990), comprendiendo en sí misma un propósito efectivamente transformador de la realidad, puesto que forma parte de ella, se inserta en su seno. Dicho de otro modo: frente a la justificada necesidad de conocer para actuar, aparentemente estaríamos hablando de actuar para transformar y -en el caminoconocer; pero se trata en efecto de un bucle recursivo donde ambas dinámicas se complementan (teorías de la complejidad), donde nuestra acción parte de un conocimiento previo que podemos construir en forma de hipótesis, de pregunta sobre la realidad.

Si trasladamos este planteamiento -y su compromiso ético- al diálogo entre pedagogía y arquitectura, o bien al campo ampliado de la concepción de los entornos como escenarios educativos, estamos hablando de una necesaria transformación de la realidad como resultado de la acción investigadora o la investigación acción; y se trata de una transformación desde una doble perspectiva, pedagógica y arquitectónica. La primera, formulando una pedagogía a través de los ambientes, la segunda, mediante el diseño del hábitat en su dimensión educadora. Queda pendiente discernir dentro de cada una de ellas quienes serían los agentes de sendas acciones.

Plantearemos así una segunda metáfora; tras la imagen del tapiz, tomaremos la metáfora de una mirada esférica, nos colocaremos una lente ojo de pez que rompe las coordenadas ortogonales del espacio, que disuelve los límites entre suelo, paredes y techos... que nos hace ver la realidad inmersos en "la fenomenología de lo redondo" que expresara ya Gaston Bachelard (1957) en su "Poética del espacio" manifestando así:

... la fórmula: "la existencia es redonda", se convertirá para nosotros en un instrumento que nos permita reconocer la primitividad de ciertas imágenes del ser. 
Una vez más, las imágenes de la redondez absoluta nos ayudan a recogernos sobre nosotros mismos, a darnos a nosotros mismos una primera constitución, a afirmar nuestro ser intimamente, por dentro. Porque vivida desde dentro, sin exterioridad, la existencia sólo puede ser redonda. (p. 203)

Trasladaremos literalmente la "fórmula" de Bachelard a nuestra mirada; con las imágenes panorámicas tomadas con lente de ojo de pez, seguiremos una metáfora visual que nos ayudará en estas líneas a ilustrar de forma radical aquello que se planteaba desde la fenomenología del espacio, actualmente investigado por la neurociencia. Volveremos a pensar así nuevamente los espacios que escudriñamos con nuestra "cámara": los entonos educativos.

\subsection{Mirar y rodar: "rolling down the hill panorama"}

Salgamos a jugar al espacio exterior acompañados literalmente por la cámara con lente de ojo de pez y veamos qué pasa. Nos encontramos un tipo de fotografía cuyo nombre no es sino un juego de infancia: rolling down the hill panorama y seguimos fascinados la extraña belleza de sus imágenes mientras recordamos la experiencia; jugar a rodar y rodar colina bajo perdiendo el sentido hasta reencontrar nuevamente el mundo. El panorama implica un movimiento envolvente del cuerpo del fotógrafo, rodeado por el mundo que ve a través de su lente; nos encontramos, como diría Bacherlard, con un mundo más bello en cuanto que es visto (figura 4).

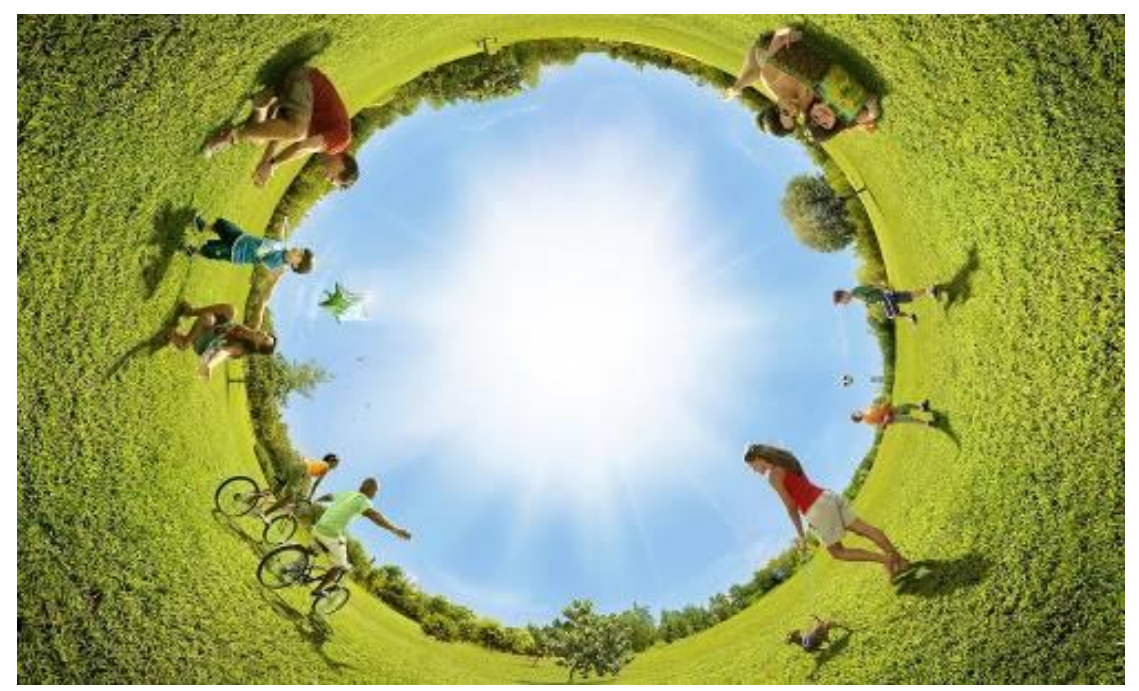

Figura 4. Fotografía panorámica $360^{\circ}$, visión de esfera ojo de pez

Fuente: Recuperado de http://desktopedia.com/playing-in-the-park-sphere-fisheye

Pese al poder de estas imágenes, a la seducción de una relación directa con la naturaleza volvemos a los espacios interiores, construidos. Con ellos, la arquitectura ha respondido durante milenios a las necesidades del habitar. Y estas necesidades de protección y relación con el mundo son anteriores incluso al surgimiento del lenguaje y su escritura, responden a aspectos primigenios de nuestra naturaleza, para conformar actualmente toda una la cultura del hábitat, nuestro mundo habitado, cultivado.

La arquitectura se sitúa en la intersección entre biología y cultura, entre nuestra necesidad de supervivencia física y de enriquecimiento de nuestra experiencia de forma significativa. Mark L. Johnson (2015) lo expresa así: "Somos criaturas de carne que organizan espacios y estructuras físicas adaptadas a sus cuerpos. Vivimos en y a través 
de nuestras continuas interacciones con entornos que son tanto físicos como culturales" 6 Los entornos educativos forman parte de este hábitat, "cultivado" pero también "biológico": requieren integrar en sí mismos las dimensiones corporal, sensorial, emocional... que emergen de forma espontánea en el juego y constituyen en sí mismos un extraordinario aprendizaje.

\subsection{La experiencia del espacio cotidiano}

Descubrir el argumento del espacio en "los entornos cotidianos de la infancia" parece sencillo, están ahí acompañándonos, con nosotros, al lado; pero ¿ivemos habitualmente nuestro entorno cotidiano?

Observaremos la experiencia del espacio como un complejo constructo que implica la memoria, la acción y lo imaginario; el espacio es soporte y constructor de metáforas que se despliegan en el tiempo alterando la realidad. Mediante las acciones de niños y niñas, se generan proyecciones y envolturas diversas en permanente construcción que transforman, de forma efectiva o imaginaria, un mundo en recíproco acoplamiento con el de la infancia. Desde el mundo adulto, frecuentemente dejamos de sentir el espacio como hecho vital en la rutina que adormece nuestra percepción de lo cotidiano; ciertos eventos despiertan sorpresivamente su presencia, ciertas prácticas creativas la revelan como esencial... y los niños más pequeños lo hacen como práctica espontánea; pero cuando buscamos los territorios de la infancia, éstos se escapan; la mirada del adulto los ahuyenta ¿Están ahí? ¿Permitimos que vivan y crezcan en empatía con el adulto? ¿O dejamos que se pierdan y quedan, quizás, sólo subyacentes?

Comprender la vinculación de espacios y tiempos como hechos indisolubles conformando un constructo complejo nos permitirá actuar de forma global sobre la experiencia del entorno educativo.

Comprender la superposición -especialmente en la infancia- de diversos planos de realidad e imaginario, nos ayudará a contemplar tanto los escenarios físicos donde tienen lugar los procesos educativos como los constructos intangibles que los acompañan.

Comprender la integración del fenómeno sensible, la acción vital, el juego y la metáfora, nos facilitará integrar las propuestas en la historia vivida, en la biografía personal y del grupo, construyendo emociones, conocimientos, experiencia: construyendo con los niños sus entornos educativos.

\subsection{Desvelando entornos, descubriendo tejidos}

La mirada con ojo de pez disuelve los límites dentro de una totalidad que integra las partes, una globalidad generadora de sentido. Nos acercamos así a la experiencia del espacio como un hecho vital extenso y fundante que abarca tanto la vivencia de un mundo a vista de pájaro como el secreto de una canica escondida en un bolsillo. Así, las consecuencias de este enfoque afectan a nuestra visión de la ciudad y sus escenarios, de la escuela y del aula, del hogar y la habitación, de los juegos y juguetes de una infancia cuya identidad se reformula constantemente desde la aceptación de su riqueza y complejidad.

${ }_{6}$ "We are creatures of the flesh who arrange spaces and physical structures fitted to their bodies. We live in and through our ongoing interactions with environments that are both physical and cultural. 
La observación y acción en entornos infantiles a diversas escalas nos dará herramientas para operar con lo existente e intervenir, quizás, en su transformación. La visión dialógica del problema a distintas escalas de aproximación: desde un planteamiento holístico que integra lo macro, lo micro y sus recíprocas influencias, desde la ciudad como inabarcable territorio de experiencias hasta el mundo íntimo del objeto en la palma de la mano, todo ello se cose con la "la transversalidad con que el soplo de la infancia recorre nuestras vidas?".

Cada entorno nos impulsa a una mirada desde su propia disciplina, con sus matices y diferencias, arrastrando sus propios saberes; es posible, sin embargo, integrar esta forma de conocimiento sin renunciar a la visión integradora, a las relaciones transversales, a las intersecciones entre saberes diversos, a la construcción de lo transdisciplinar.

\subsection{De la ciudad a la escuela}

Lo urbano como entorno educativo nos remite al estudio de la ciudad como un fenómeno vivo, como hábitat que refleja una cultura, como el tejido de relaciones de sus habitantes, entre ellos los niños (figura 6). El reto se encuentra en cómo integrar -o no expulsar- al niño en un medio urbano y sus conflictos sin superarlos en base a una segregación de funciones que dinamita la "ciudad viva", un territorio complejo de riqueza inagotable como fuente de experiencia. Con los referentes de Michel de Certeau, Jane Jacobs y Henri Lefebvre, hemos realizado diversas aproximaciones a la ciudad como territorio de la infancia. Rindiendo tributo siempre al clásico The child in the city (1978) de Colin Ward, nos sumergimos en la ciudad acompañados por la infancia, en sus prácticas del espacio urbano, vemos los mismos cruces, las mismas calles, los mismos escalones, los mismos portales; pero desde otra mirada.

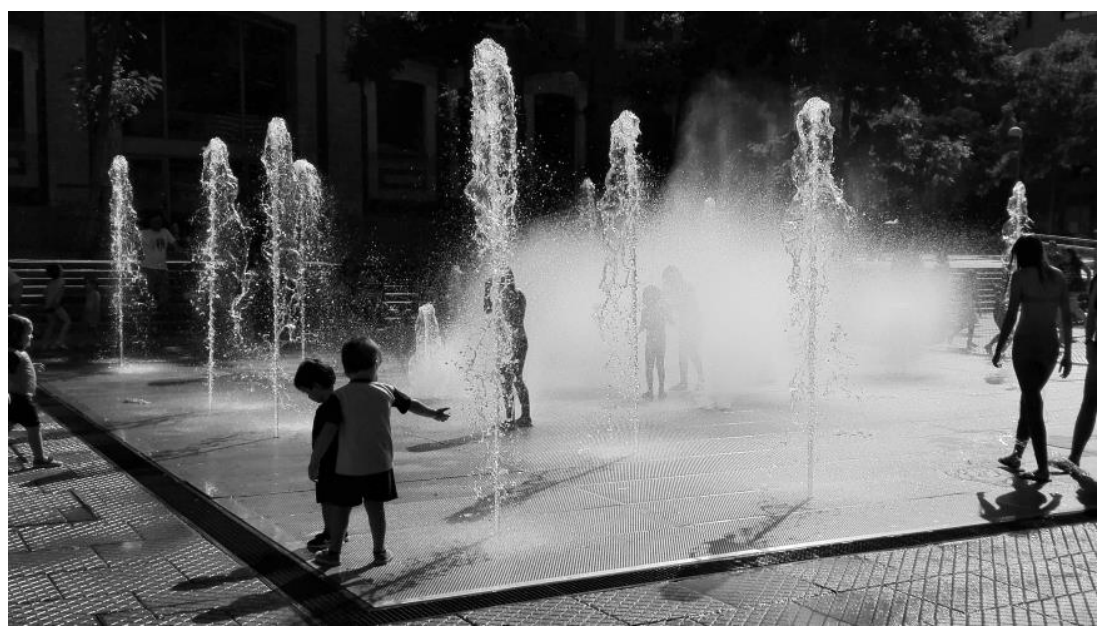

Figura 6. El agua, el calor y la luz activan sensorialmente un espacio de juego urbano Fuente: Elaborado por Eslava (2015).

Michel de Certeau (2000), en "La invención de lo cotidiano", funda de nuevo en la infancia la experiencia del espacio y con ella deshace las superficies legibles de la ciudad planificada:

\footnotetext{
7 Referencia al blog "La ciudad viva”, entradas escritas por INFANS' FANS, autores varios. http://www.laciudadviva.org/blogs/?author $=95$
} 
Practicar el espacio es pues repetir la experiencia jubilosa y silenciosa de la infancia; es, en el lugar, ser otro y pasar al otro. [...] La infancia que determina las prácticas del espacio desarrolla en seguida sus efectos, prolifera, inunda los espacios privados y públicos, deshace sus superficies legibles, y crea en la ciudad planificada una ciudad "metafórica" o en desplazamiento. (Certeau, 2000, p. 122)

La experiencia del espacio en la infancia es hoy indisociable del territorio de lo urbano, donde lo extraordinario dialoga con lo cotidiano y lo real con lo imaginario (figura 7).

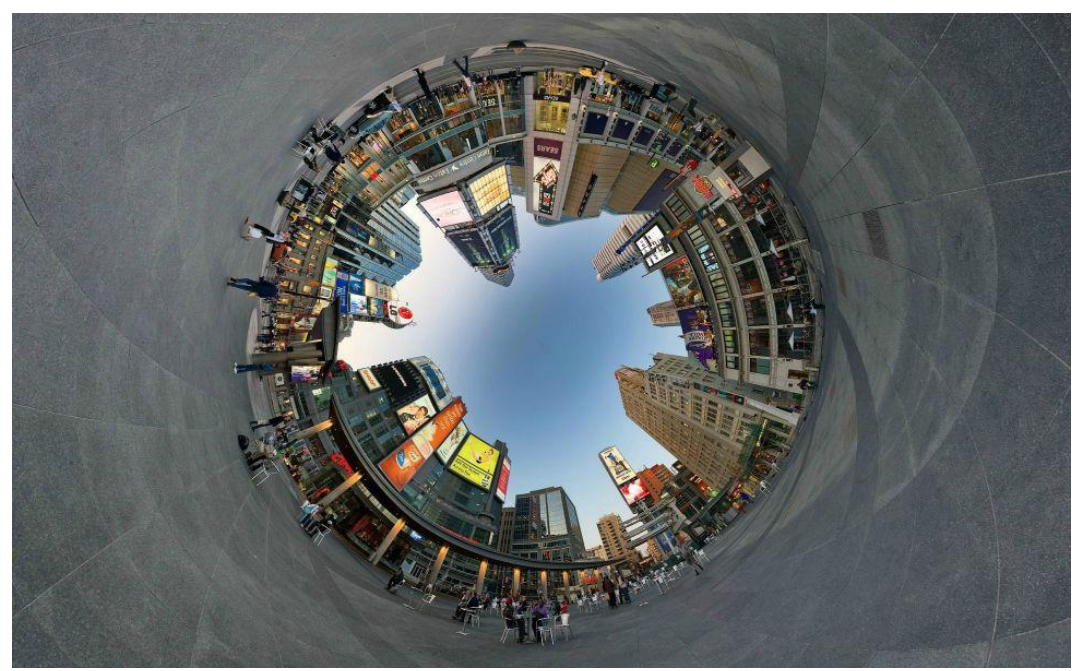

Figura 7. Fotografía panorámica $360^{\circ}$, visión de escena urbana con lente ojo de pez Fuente: Recuperado de http://randomwallpapers.net/fisheye-city-cities_w358536.

En el libro "Territorios de la infancia" (Cabanellas y Eslava, 2005), mostrábamos la ciudad como campo de juego, nos acercábamos a los playgrounds y tratábamos la escuela como como un interfaz de mediación con el mundo cuya identidad surgía desde el diálogo entre arquitectura y pedagogía. Y lo hacíamos desde la aproximación investigadora de Isabel Cabanellas, que trataba de comprender y transformar un todo complejo interactuado por sus partes, un microcosmos al cual nos acercábamos desde una visión holística que contemplara las experiencias y emociones. En este contexto, operando como las "redes dentro de redes" que mencionábamos al inicio, resulta vital el planteamiento del proyecto de escuela como un ámbito de mediación en un medio urbano, conectando su comunidad de usuarios con la ciudad.

La escuela puede ser disfrutada como un oasis en el medio urbano, un territorio simultáneamente segregado y conectado que posibilita el encuentro social de niños y adultos, un micromundo que mira al mundo y que es visto. Contribuye a crear y expresar de forma visible una cultura de la infancia. La inserción de la escuela en el contexto urbano del barrio, en diálogo con su entorno edificado hace de ella una herramienta de mediación clave entre "los niveles del espacio existencial" (NorbergSchulz, 1975), como bisagra entre las cosas, la casa y la ciudad, la escuela introduce al niño a un mundo que está fuera, más allá de sus muros, de las tapias y verjas carcelarias que significan escisión. La escuela puede abandonar su rigidez decimonónica y establecer un diálogo con una de las expresiones propias de la ciudad contemporánea, los playground; los campos de juego articulan una nueva sensibilidad, su diseño implica el desarrollo de otras estrategias creativas, se insertan en la trama productiva de la ciudad como un lugar de juego y disponibilidad lúdica, como un laboratorio experimental, un 
'aire libre' con sus nuevos códigos de diseño y/o de construcción participativa. Finalmente, nos introducíamos en el interior de la escuela de la mano de Alfredo Hoyuelo que nos ofrecía una síntesis de los planteamientos Reggianos comprendiendo la escuela como un ámbito estético educativo, la ética de podía constituirse desde la estética. Se planteaban así los "territorios de la infancia", desde la complejidad del conjunto y las partes, tanto como desde las interrelaciones entre pedagogía y arquitectura.

Posteriormente, en el artículo "Ambientes para la infancia: escuelas entre experiencia y proyecto” (Eslava y Cabanellas, 2014), realizábamos una aproximación mediante un posible decálogo de puntos clave, que buscaba ampliar el foco abriendo el diálogo entre arquitectura(s) y pedagogía(s), para enfrentarnos a una realidad que arrastra inercias difíciles de cambiar. Mirando de forma global, nos acercábamos a la escuela como una totalidad, desde la memoria de la infancia y desde el vínculo emocional, desde la relación con el mundo y la responsabilidad en la construcción de experiencias:

\begin{abstract}
Nos encontramos en un medio, el de la escuela, cuya arquitectura persigue en el mejor de los casos ser el reflejo de las diversas pedagogías que le dan origen. Se plasmaría así un diálogo abierto entre disciplinas, un encuentro donde el espacio deviene un hecho pedagógico de primer orden. Pero en la mayoría de los casos pedagogos y maestros se encuentran con un sistema educativo preexistente cuyos espacios y prácticas parecen estar predeterminados; frente a ello, juguemos seriamente a reinventar la experiencia de lo cotidiano de la mano de los niños, construyendo e investigando en entornos educativos vivos. (Eslava y Cabanellas, 2014, p. 51)
\end{abstract}

Cerrábamos entonces nuestra aproximación con una llamada, y a modo de conclusiones, abríamos las puertas del aula.

\title{
1.10. El aula como entorno educativo
}

Siguiendo este recorrido, nos sumergiremos a continuación en el espacio del aula. Un aula que es actualmente la unidad, el módulo básico de una mayoría absoluta del sistema educativo mientras, paralelamente, la razón de ser de su necesidad ha sido ampliamente cuestionada a lo largo de la modernidad por modelos alternativos que proponen su disolución, su redefinición, su desaparición o su integración en pos de otros enfoques educativos y sus diversos espacios.

Siguiendo la síntesis que traza Pineau, Dussel y Caruso (2001), podemos afirmar que el aula tradicional ordenó las prácticas cotidianas a partir del triunfo final y avasallante del método simultáneo, gradual o frontal:

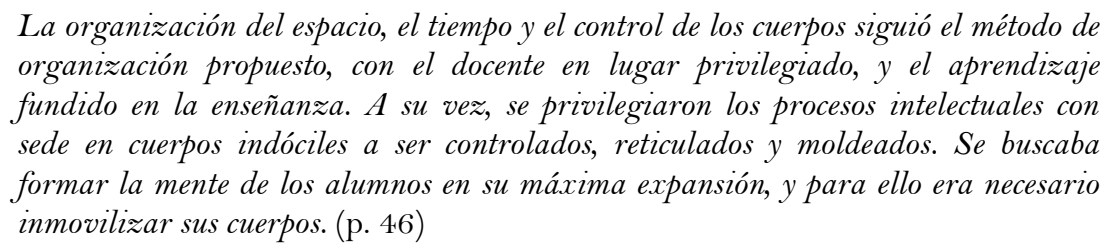
organización propuesto, con el docente en lugar privilegiado, y el aprendizaje fundido en la enseñanza. A su vez, se privilegiaron los procesos intelectuales con sede en cuerpos indóciles a ser controlados, reticulados y moldeados. Se buscaba formar la mente de los alumnos en su máxima expansión, y para ello era necesario inmovilizar sus cuerpos. (p. 46)

Si acudiéramos a los orígenes, volviendo sobre una historia de los espacios educativos ver, entre otros, Escolano (2000)-, descubriríamos cómo en base a la escuela unitaria o la escuela al aire libre, la necesidad y definición del aula resultan radicalmente opuestas a la actual seriación de unidades en la escuela graduada, predominantemente urbana; esta última, se comprende históricamente como un progreso, surge asociada al desarrollo industrial y el crecimiento de los núcleos urbanos. 
Sin embargo, vivimos hoy un periodo post industrial que resulta prisionero de los logros precedentes y las limitaciones que los acompañan: la producción seriada frente a la manual, lo cuantitativo frente a lo cualitativo, la repetición frente a la diferencia, el trabajo frente a la creatividad... La progresión de la estandarización aumenta conforme crece la edad, llegando a su culmen en las etapas obligatorias de la educación secundaria, donde desaparece cualquier vestigio de la escuela como espacio de relación, donde ya podemos construir arquitecturas que racionalicen al máximo el número pues, los casi adultos, sobrevivirán en ellas.

El conjunto de la escuela se redefine recíprocamente por sus aulas, por lo que sucede en ellas y por cómo se relacionan entre sí y con el conjunto, mediante vínculos, transparencias, ósmosis; abriendo o cerrando puertas, borrando o estableciendo límites, demoliendo o construyendo muros. La identidad múltiple de la escuela como membrana, como interface, como campo o entorno de mediación entre el yo y el mundo, entre lo individual y lo colectivo, entre lo cercano y lo lejano, lo que se experimenta y lo que se conoce... se reproduce de forma homóloga en el aula. El aula es un microcosmos y como tal, la parte contiene en sí misma la complejidad de la escuela, la totalidad en que se inscribe.

Diversos enfoques pedagógicos buscan escapar a la actual realidad imperante y se enuncian tomando el aula como lema y adjetivándolo con diversas alternativas pedagógicas. El aula toma el mando y parece capaz de representar el conjunto de intenciones de la escuela y su pedagogía: Aula de experiencia, Aula de inmersión, Aula de innovación, Aula de rincones, Aula de integración, Aula ecológica, Aula experimental, Aula de diversidad, Aula vivencial, Aula cognitiva, Aula activa... En su definición el lenguaje implica frecuentemente un componente espacial, que se convierte en metáfora de una pedagogía: Aula abierta, Aula virtual, Aula taller, Aula al aire libre, Aula invertida, Aula expandida...

Toda esta variedad de términos refleja una intensa búsqueda de dinamizar, transformar y actuar en términos pedagógicos; sin embargo, el statu quo del aula, continúa siendo de forma general el de su zonificación, en el mejor de los casos, en funciones diversas; o el de su segregación, en la mayoría de los casos, en dos áreas netamente diferenciadas, la de los niños y la del adulto. No podemos aceptar hoy día estas concepciones del entorno como un continente vacío, como simple área disponible a rellenar; la fragmentación de la unidad de aula en subespacios ha introducido una diversidad necesaria, pero es necesario señalar que no podemos asignar un área estanca al juego libre ni otorgar un rincón a la capacidad de simbolizar, pues son potencias transversales, son dinámicas capaces de conectar múltiples espacios y tiempos, reales e imaginarios. Siguiendo nuestro planteamiento, el aula debe ser una zona de adecuación cognitiva y emocional, un lugar que facilita el "acoplamiento estructural" entre el yo y los otros, entre mi mundo y el mundo. Si el aula es un entorno educativo podríamos considerar el propio espacio del aula como una metáfora del aprendizaje.

\section{El aula re-imaginada}

Finalmente nos sumergiremos en la unidad básica del actual sistema educativo, el aula, para re imaginarla. Entre sus cuatro paredes, jugaremos hasta sentir la necesidad de integrar las experiencias de aprendizaje en un escenario relacional, cosido por vínculos, 
un tejido transformador cuyos hilos se insertan en la realidad conectando lo cognitivo y lo emocional (figura 8).

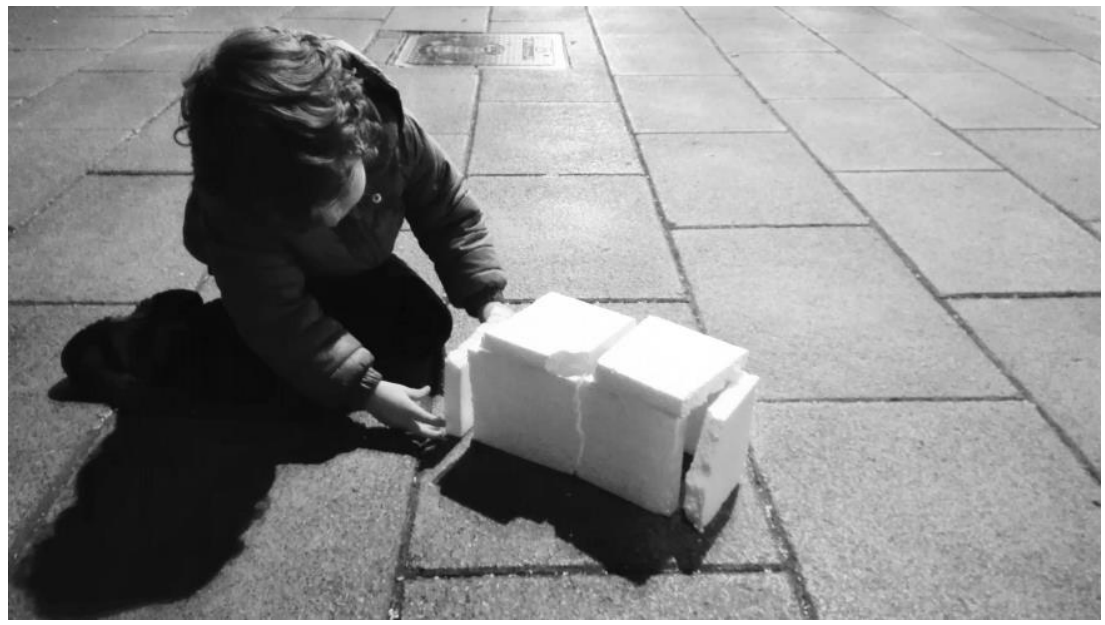

Figura 8. Un niño construye su pequeño habitáculo, un fragmento de privacidad en la ciudad

Fuente: Elaborado por Eslava (2017).

\subsection{El aula en "el campo expandido"s}

Vamos a introducirnos hoy en el interior del aula, un aula cuya definición, límites e identidad cuestionaremos desde una visión ampliada, desde su concepción como una membrana invisible que media entre el yo, el nosotros y los mundos que se construyen en la propia acción. Desde los planteamientos sistémicos y de las teorías de la complejidad, podemos concebir transformaciones globales que surgen tanto a partir del conjunto como de alguna de sus partes, por lo que no restaremos dosis de utopía a las acciones emprendidas desde el aula: allí donde, como mínimo, podemos hacer todo.

Las condiciones de continuidad, transparencia y fluidez que definen los ámbitos contemporáneos se encuentran en diálogo con el concepto de "educación expandida" sino como inclusión de un aprendizaje que está "en todas partes" y no sucede exclusivamente en el aula tradicional: puede producirse en cualquier momento y en cualquier lugar; se accede al mismo por vías diversas; se participa activamente en la generación de un conocimiento que se construye en red. La experiencia educativa se prolonga fuera del aula, tanto como incorpora el mundo al aula, enriqueciendo el aprendizaje en un diálogo con la vida.

\section{Con ojos de pez}

Acompañados por las nuevas cámaras $360^{\circ}$, y su "otra forma de mirar" ${ }^{10}$, encontramos poderosas imágenes: el mundo exterior condensado en una esfera, el mundo interior

\footnotetext{
8 La redefinición de un campo disciplinar mediante el término 'expandido' tiene su origen la teoría del arte, en el influyente ensayo de Rosalind Krauss titulado: "La escultura en el campo expandido" publicado en el libro "La posmodernidad” editado por Hal Foster (1983), pp. 59-75.

9 El término "educación expandida" expresa una prolongación del entorno de aprendizaje incluyendo los procesos educativos más allá de la escuela: combina elementos propios de la educación formal, la enseñanza informal e integra el uso de las nuevas tecnologías.

${ }^{10}$ En el clásico de John Berger, “Otra forma de contar”, se plasma el vínculo entre 'mirar' y 'contar', entre la mirada hacia el mundo y su narrativa.
} 
como un continuo esférico donde no se diferencian planos de suelo, techo o paredes. ¿Es el aula el espacio entre sus cuatro paredes? ¿Las necesita? ¿De qué hablamos entonces si el aula no son sólo sus cuatro paredes?

Veamos cómo afecta esta nueva mirada, esta forma de mostrar un espacio interior, a nuestro concepto y experiencia del mismo. Así, las cámaras 360 grados, encontramos una nueva forma de documentar, y comunicar los espacios interiores; veamos cómo la herramienta transforma nuestra visión y reflexionemos sobre ello en el contexto educativo.

Disponemos de estas herramientas con un simple (o complejo) smartphone que llevamos en el bolsillo... los niños también disponen de ello y lo manejan con soltura. Podemos documentar, estudiar, registrar, diagnosticar con estas visiones divergentes (aunque no sólo) nuestros espacios del aula. Otra forma de mirar da paso a "otra manera de contar", parafraseando a John Berger (2007). Así, podríamos imaginarnos las estancias de la escuela como si fueran espacios esféricos, como si fueran las burbujas que habitamos colectivamente y durante muchas horas cada día. Nuestro propósito en estas líneas es sólo señalar el cambio de mirada que hace esto posible para sí comenzar a acceder al interior del aula por inmersión, como si fuéramos un ojo de pez nadando en el aire del aula, en un "aula líquida".

\subsection{Las metáforas del aula}

El lenguaje emplea múltiples metáforas que surgen al expresar conceptos mediante imágenes que atrapan de la naturaleza espacial de los entornos cotidianos que vivimos. Así, el espacio del rectangular del aula y su geometría ortogonal se reflejan en el lenguaje marcándolo fuertemente, estamos entre cuatro paredes contamos cuatro esquinas. En la clausura del recinto, puerta y ventana son las únicas bisagras que permiten vías de escape -reales y psicológicas- de un espacio y un tiempo fuertemente acotado. Suena el timbre, es la hora, nos asalta un irrefrenable impulso de salir.

\section{Las cuatro esquinas}

En la sencillez de la habitación, la esquina se convierte en singularidad, en hito, en articulación de un espacio demasiado homogéneo. Decía Leo, niño en primer curso de primaria: "mamá, no te preocupes porque me castiguen tanto, se aprende igual desde la esquina!", expresando así la crítica integración de un "modelo" educativo y su espacio. Desde la esquina, surgen direcciones diagonales, es posible ver el aula de otra forma, el espacio se dinamiza. Jugar a "las cuatro esquinas" es meterse cinco niños en el lugar de cuatro, es apelar a lo imposible y convertirlo en regla. La esquina es un lugar, una acción, una actitud, una emoción: es apostarse en la esquina o quedar a la vuelta de la esquina: ¡metáforas del lenguaje, entre las cuales, surge el "córner”!

Frente a la zonificación, amueblamiento y ocupación estática que reflejaría cualquier plano de un aula, nos sorprende la representación dinámica de las tácticas en el campo de fútbol, el rectángulo se define como campo de juego dinámico, lugar de estrategias en movimiento, relaciones, posiciones en el espacio. ¿Seríamos capaces de representar así los acontecimientos del aula? ¿Podríamos grafiar los movimientos, jugadores y relaciones del escenario del aula? ¿Podríamos llevarlo a cabo con acciones eficaces, compartidas, accesibles? 


\section{Entre cuatro paredes}

El entorno construido en que vivimos, muestra un evidente predominio de lo ortogonal que queda reflejado en un lenguaje cuya condición espacial articula nuestra concepción del mundo: las cuatro patas de la mesa se constituyen en metáfora de cuatro ideas fundamentales construyéndose así sucesivamente metáforas donde predomina la imagen estática de una edificación. Las transformaciones de paradigma cuestionan precisamente estos aspectos básicos que conforman nuestra visión del mundo: aceptamos el vivir entre cuatro paredes o no lo hacemos y las cuestionamos para -desde una indómita curiosidad- buscar más allá; busquemos una "quinta pared" en cada propuesta pedagógica, en cada transformación del espacio, como un nuevo horizonte de posibilidades. Pero seguimos emplazados en la pared opaca, cerrada, inerte, aquella que permite estar "contra la pared", castigado por el muro que nos devuelve su respuesta impasible. El aula contenida entre cuatro paredes no se ciñe a sus límites físicos: desde una voluntad de representación del mundo puede impulsar su búsqueda vital. La envolvente física del aula se concibe, así como un interface entre lo próximo y lo lejano, entre real y virtual, entre lo visible y lo invisible. Sus paredes, techos y suelos son membranas de mediación con el mundo (figura 9).

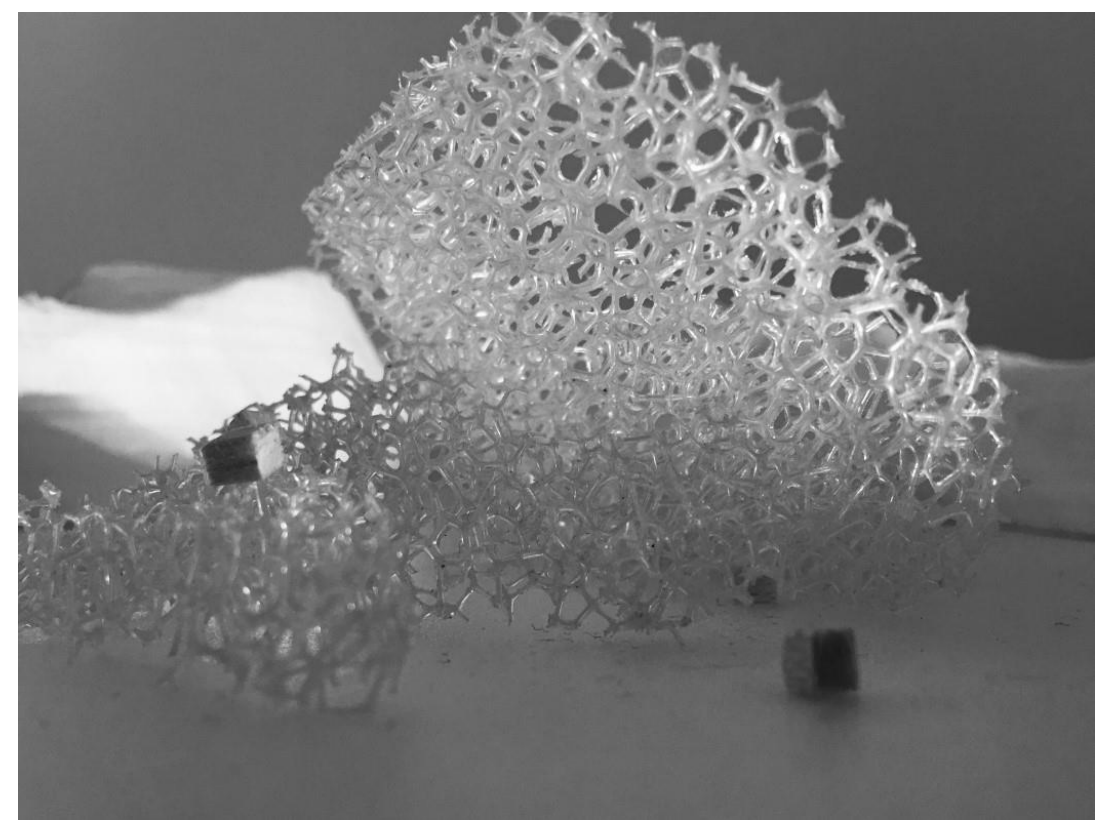

Figura 9. Otros materiales, orgánicos, conforman otras posibles estructuras espaciales Fuente: Elaborado por Valencia (2016).

Juguemos nosotros con el aula, con sus cuatro paredes, apropiémonos de ellas, incorporémoslas a nuestro mundo demoliendo las paredes de ladrillo del aula convencional: ¿Y si fueran transparentes? ¿Y si fueran cortinas? ¿Y si fueran pizarras? ¿Y si fueran multicapas? ¿Y si fueran nuestras?

\section{El concepto de "la cuarta pared"}

El concepto de "la cuarta pared" surgió del teatro en un momento de cambio entre el simulacro y la experiencia real, en que los actores pasaron a construir la escena con autonomía del público, mediante una representación realista del mundo que era visto a través del diafragma transparente de aquella cuarta pared. 
Si transportásemos esta noción al aula vinculándola al resto de la escuela, sería posible una doble mirada, un doble espacio de representación, desde el aula a la escuela y viceversa. Para después jugar con esta relación a voluntad con una pared activa donde podamos proyectarnos, dibujar, pintar, reflejarnos o escondernos..., subir el telón, bajar el telón en un juego cambiante que nos permita sentir de otra forma, disruptiva, la pesada contingencia de las cuatro paredes y solo cuatro... Capas diversas se superponen: una pared de vidrio, impresiones, textos y transparencias sobre ella; una cortina que la cubre cuando se cierra el telón, paneles de pizarra blanca, negra; ventanas físicas y virtuales, todo ello nos permite la apropiación y enriquecimiento de un espacio que es actualmente la unidad identitaria del sistema educativo. Proyectemos procesos, escribamos sobre las paredes, grafiemos, construyámoslas activamente. Imaginemos abrir el aula al espacio exterior, al mundo fuera de la escuela, olvidando la realidad física de los muros que nos encierran en el emerger de un constructo creativo.

El aula que juega al "como si fuera..."

Hablaremos por tanto de un aula que pueda jugar al "como si", desde la ambigüedad necesaria para el juego simbólico, un escenario transformable en la acción, un espacio físico y unos tiempos cronológicos que desatan otros espacios y tiempos, imaginarios, superpuestos.... que acaecen en la acción, en el relato, transformando las coordenadas de los primeros. Volviendo a nuestra metáfora del tejido invisible, re imaginemos el aula, un aula que -como un tapiz- atrapa el mundo con las imágenes que construye... Re imaginemos el aula "como si fuera" una membrana en ósmosis entre el yo, el nosotros y el mundo; como un interfaz de encuentro, de diálogo, de vínculo; como un entorno social y de narración, de relación; el aula como un entorno individual y de experiencias...

Re imaginemos el aula "como si fuera" un juguete incompleto capaz de recibir, de integrar todos los anteriores conceptos y aquellos que surjan, nuevos, en un proceso de descubrimiento y metamorfosis: un territorio múltiple, un escenario lúdico...

Re imaginemos el aula "como si fuera" un diálogo entre términos en dialógica, entre realidad y representación; entre interioridad y exterioridad; entre espacio y tiempo; entre parte y todo; entre espacio de protección y de emancipación; entre lo real y lo imaginario...

Re-imaginemos "como si fuera" un interfaz mediador, re imaginemos sus cuatro paredes como un horizonte, como capas o envolventes sucesivas que disponemos y retiramos al igual que el telón de un escenario...

Re imaginemos el aula "como si fuera" un escenario metafórico; hagámoslo desde el poder transformador de la metáfora, desde su capacidad para hacernos jugar, soñar y transformar el entorno, sentir de otra forma sus espacios y sus tiempos, para proyectarlos creativamente.

\section{En busca de un nuevo paradigma integrador}

Ámbitos construidos o no, exteriores o interiores, reales o virtuales, éstos, conforman los lugares donde se produce el descubrimiento del aprendizaje, o como diría Edgar Morin (1986), el conocimiento del conocimiento, la experiencia de la experiencia, la emoción de la emoción o -como la obra de Jean Duvignaud (1980) el juego del juego(figura 10). 


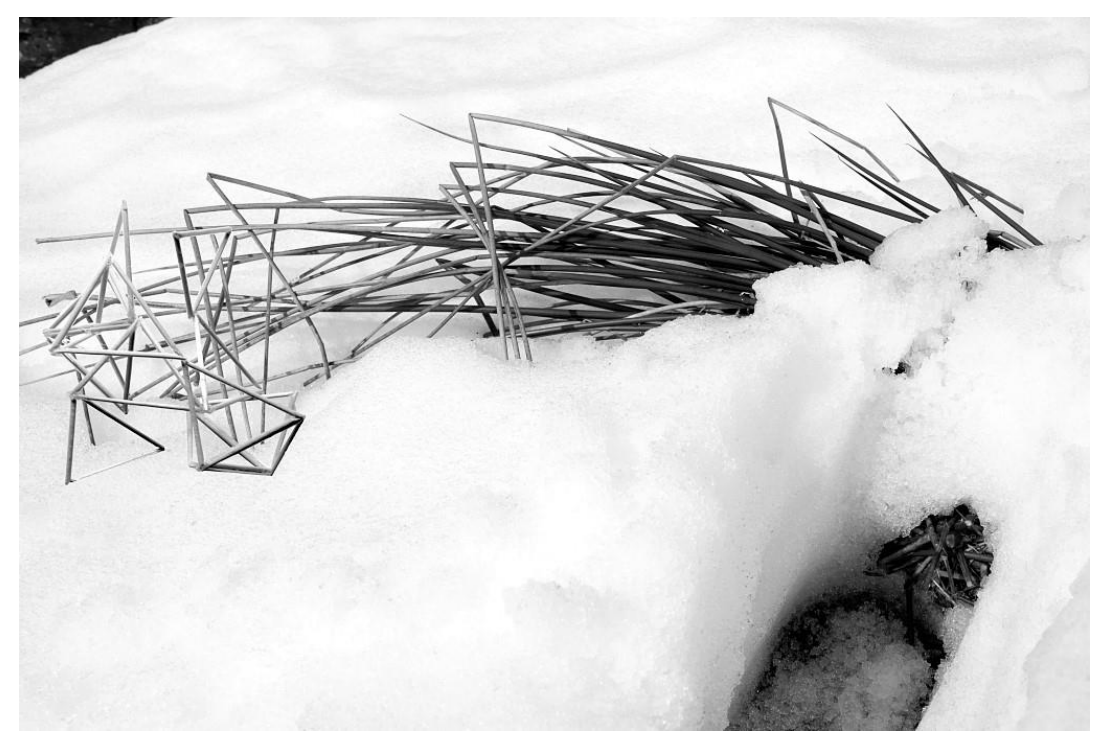

Figura 10. Las formas de la naturaleza entran en diálogo con la geometría de lo construible

Fuente: Elaborado por Muñoz (2016).

Re-Imaginemos sus dimensiones, sus relaciones, sus lugares -suelos, cojines, círculos, áreas, manchas- Recursos escenográficos, como estructuras y soportes que nos permitan colgar, suspender objetos; re imaginemos el techo como un plano activo... Objetos y entornos diversos en permanente construcción transforman, de forma efectiva o imaginaria, un ámbito en recíproco acoplamiento con el de la infancia. Re imaginemos sus significados... indaguemos en aquellos espacios míticos que podrían transformar un espacio de aprendizaje como "imágenes fuerza" plenas de carga simbólica; estaríamos en el primer paso de un proceso que podría llegar a proponer lugares tan 'significantes' como polisémicos, que permitan por tanto dejar abiertos los significados, como un relato con múltiples finales.

\section{El aula como ámbito sensible: empatía de los sentidos}

Comprender el aula como espacio fenomenológico nos puede ayudar a transformarla de forma global y en sus múltiples dimensiones. La fenomenología de la experiencia del espacio, la polisensorialidad, lo háptico o la propiocepción que a lo largo de su trayectoria trataron filósofos como Maurice Merlau-Ponty 1945) o la interpretación mítica de Gaston Bachelard1957, encuentra hoy vías de desarrollo tanto a través del arte como en los avances de la neurociencia. Neuro- pasa a ser un prefijo que acompaña a otras áreas del conocimiento, como la arquitectura y la educación, estudiando la interacción compleja del ser con el mundo y buscando la comprensión de su experiencia del mismo. En analogía al complejo constructo de las conexiones 'neuronales', los entornos de aprendizaje favorecerían la desaparición estructuras fijas en pos de redes móviles; todo ello se reflejaría en ámbitos lábiles, fluidos, continuos...

\section{El aula como ámbito tangible: semántica del cuerpo}

Describimos mediante términos diversos los entornos cotidianos de la infancia; hablamos de sus territorios, sentimos sus lugares o proyectamos sus espacios; evidenciamos campos de juego, intuimos ámbitos primigenios y poblamos su mundo de objetos; y lo hacemos desde la conciencia de que el sentido del espacio se despliega como 
experiencia corporal, especialmente rica e intensa en la infancia, implicando eventos cognitivos vitales. El aula como ámbito acompaña procesos cognitivos y corporales, se constituye en metáfora de una mente in-corporada: como desarrolla Juhani Pallasmaa (2014) en "La imagen corpórea", el cuerpo es cognoscitivo.

El aula como ámbito inasible: anatomía de la mente

Nos sumergimos ahora más aún si cabe en el interior del aula, y lo haremos re imaginándola en mímesis con los procesos de aprendizaje que alberga, procesos vitales que reflejan espacios mentales y corporales, tanto individuales como del grupo. La analogía entre el ámbito del aula y los procesos cognitivos y emocionales nos permite comprender sus espacios y sus tiempos más allá de sus cuatro paredes, de sus cuatro cuartos de hora. Sus paredes son los huesos de nuestro cráneo, pero no los límites de nuestra mente.

El aula como escenario de procesos, cognitivos y emocionales, metáfora de un espacio donde razón y emoción se incorporan en reciprocidad. El aula como espacio de aprendizaje: como metáfora de un conocimiento integrador, corporal, sensible, emocional (figura 11).

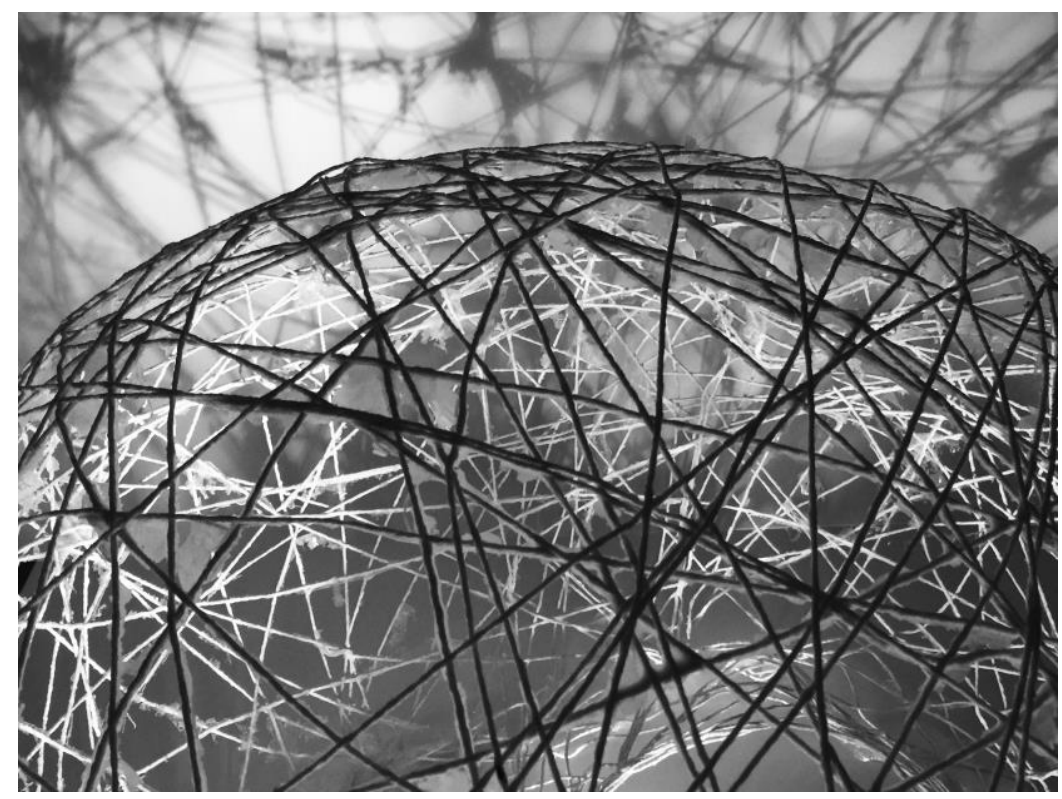

Figura 11. Maqueta de un espacio imaginario, metáfora del nido Fuente: Elaboración por Lallana (2016).

Como final de nuestro recorrido, hemos esbozado una serie de metáforas del aula re imaginando nuevamente este escenario educativo, un fragmento capaz de apelar a la totalidad del mundo en que se inserta: la realidad del aula sería la expresión tangible de una realidad intangible, el tejido invisible entre educación y entorno.

Podemos concluir que el entorno, en tanto que educativo, implicaría el acoplamiento óptimo entre sujetos y contextos diversos que entran en resonancia en el proceso de aprendizaje; un entorno educativo sería en consecuencia objeto de una doble reflexión, sobre el escenario sensible y sobre el constructo invisible que se tejen conjuntamente, la trama y urdimbre de un tejido que debemos, hoy, hacer visible. 


\section{Agradecimientos}

Agradecemos a Virginia Lallana, Natalia Muñoz y Christian Valencia las imágenes de las maquetas que realizaron durante el curso 2015-2016 en la Universidad Antonio Nebrija con la docente Clara Eslava. Se realizaron propuestas diversas en una aproximación creativa a los espacios de aprendizaje desde las miradas del arte, arquitectura y diseño. El conjunto de trabajos realizados se encuentra en la dirección web: https://learningfromhabitat.wordpress.com/

Agradecemos a Diego García-Setién la sensibilidad de su mirada hacia el mundo de la infancia.

\section{Referencias}

Cabanellas I. y Eslava, C. (Coords.). (2005). Territorios de la infancia. Diálogos entre pedagogía y arquitectura. Barcelona: Graó

Bachelard, G. (1957). La poética del espacio. Ciudad de México: Fondo de Cultura Económica.

Berger, J. (2007). Otra manera de contar. Barcelona: Gustavo Gili.

Capra, F. (1996). La trama de la vida, una nueva perspectiva de los sistemas vivos. Barcelona: Anagrama.

Certeau, M. (2000). L'invention du quotidien. Arts de faire. París: Gallimard.

Chaves, N. (2005). El diseño invisible: siete lecciones sobre la intervención culta en el hábitat humano. Buenos Aires: Paidós.

Duvignaud, J. (1980). El juego del juego. Ciudad de México: Fondo de Cultura Económica.

Eslava, V. y Cabanellas, I. (2014). Ambientes para la infancia: escuelas entre experiencia y proyecto. RELAdEI - Revista Latinoamericana de Educación Infantil, 3(2), 51-80.

Elliott, J. (1990). La investigación-acción en educación. Madrid: Morata.

Foster, H. (1983). La posmodernidad. Barcelona: Kairós.

Hertzberger, H. (1991). Lessons for students in architecture. Rotterdam: 010 Publishers.

Johnson, M. L. (2015). The embodied meaning of architecture. Cambridge, MA: The MIT Press.

Lefaivre, L., Hall, G. y Döll, T. (2007). Ground-up city: Play as a design tool. Rotterdam: 010 Publishers.

Maturana, H. y Varela, F. (1984). El árbol del conocimiento. Las bases biológicas del entendimiento humano. Madrid: Debate.

Montaner, J. M. (1997). La modernidad superada: arquitectura, arte y pensamiento del siglo XX. Barcelona: Gustavo Gili.

Morin, E. (1986). El método III. Madrid: Cátedra.

Morin, E. (2015). Enseñar a vivir. Manifiesto para cambiar la educación. Buenos Aires: Nueva Visión.

Norberg-Schulz, C. (1975). Existencia, espacio y arquitectura. Barcelona: Blume.

Norman, D. A. (2005). El diseño emocional. Barcelona: Paidós. 
Pallasmaa, J. (2014). La imagen corpórea. Imaginación e imaginario en la arquitectura. Barcelona: Gustavo Gili.

Pineau, P., Dussel, I. y Caruso, M. (2001). La escuela como máquina de educar: tres escritos sobre un proyecto de la modernidad. Buenos Aires: Paidós Ibérica.

Robinson, S. y Pallasmaa, J. (Eds.). (2015). Mind in architecture. Neuroscience, embodiment, and the future of design. Cambridge, MA: The MIT Press.

Sloterdijk, P. (2009). Esferas I (Burbujas). Madrid: Siruela.

\section{Breve CV de la autora}

\section{Clara Eslava}

Arquitecta por la ETSAUN (2000), investiga sobre relaciones entre arquitectura y pedagogía, con foco en la experiencia del espacio en la infancia y los procesos creativos. Es doctora en teoría del proyecto por la UPM (2015) en el área de teoría del proyecto con la tesis titulada "Huellas de infancia en el impulso creativo. Ámbitos primigenios" realizada en la ETSAM, UPM, Madrid, bajo la dirección de D. Juan Navarro Baldeweg. Cofundadora desde 2004 de 'eslava y tejada arquitectos', desarrolla su labor profesional como arquitecta en paralelo a la docencia; actualmente es profesora adjunta en la Universidad Antonio de Nebrija, Madrid, en las áreas de arte, diseño y arquitectura. Coordinadora y coautora del libro "Territorios de la infancia" Grao (2005), cuenta con numerosas ponencias y publicaciones en diversos medios especializados. ORCID ID: 0000-0002-6063-4166. Email: cec@eaaestudio.com 